Огляди літератури, оригінальні дослідження, погляд на проблему, випадок з практики, короткі повідомлення УДК 616.12-008.331.1-06:616.13-007.272-085.225.2

DOI 10.11603/1811-2471.2019.v0.i2.10369

\title{
ВПЛИВ СТАНУ ВЕГЕТАТИВНОЇ НЕРВОВОЇ СИСТЕМИ НА ГЕМОДИНАМІКУ ПАЦІЄНТІВ 3 ГІПЕРТОНІЧНОЮ ХВОРОБОЮ У ПОЄДНАННІ $З$ ОБЛІТЕРУЮЧИМ АТЕРОСКЛЕРОЗОМ НИЖНІХ КІНЦІВОК
}

\author{
๑Л. С. Бабінець, Л. Я. Федонюк, В. В. Білочицька, Ю. Я. Коцаба \\ Тернопільський національний медичний університет імені І. Я. Горбачевського МОЗ України
}

РЕЗЮМЕ. При вивченні стану центральної гемодинаміки (ЦГ) та периферійної гемодинаміки (ПГ) у пацієнтів з гіпертонічною хворобою (ГХ) у поєднанні з облітеруючим атеросклерозом нижніх кінцівок (ОАНК) важливим $\epsilon$ питання вегетативної нервової регуляції.

Мета дослідження - вивчити вплив стану вегетативної нервової системи на центральну і периферійну гемодинаміку пацієнтів з гіпертонічною хворобою у поєднанні з облітеруючим атеросклерозом нижніх кінцівок.

Результати. У пацієнтів з гіпертонічною хворобою у поєднанні з ОАНК після проведених реконструктивних оперативних втручань встановили три типи гемодинаміки: гіперкінетичний тип - у 32,1 \% пацієнтів (підвищення Сl

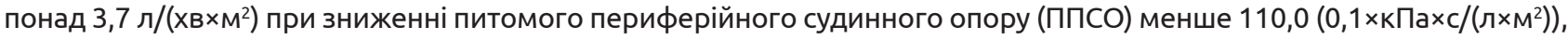
гіпокінетичний тип - у 38,7 \% (зниження СІ менше 2,2 л/(хвхм²) при одночасному підвищенні ППСО понад 190,0 $\left(0,1 \times \kappa П а \times c /\left(л \times м^{2}\right)\right)$; еукінетичний тип - у 29,2 \% (значення Cl і ППСО були у межах вищеназваних типів гемодинаміки).

Висновок. При гіпертонічній хворобі у поєднанні із ОАНК з гіпокінетичним типом гемодинаміки у 59,1 \% пацієнтів було констатовано підвищення тонусу парасимпатичного компонента ВНС і наявність недостатньо розвинутого колатерального русла нижніх кінцівок, а в 89,3 \% з еу- та гіперкінетичним типами гемодинаміки - переважання симпатичного компонента ВНС із достатньо розвинутим колатеральним руслом, що здатне до посилення функціонального навантаження.

КлючовІ СлОВА: гіпертонічна хвороба; облітеруючий атеросклероз нижніх кінцівок; вегетативна нервова система; периферійна та центральна гемодинаміка.

Вступ. При вивченні стану центральної (ЦГ) та периферійної гемодинаміки (ПГ) у пацієнтів з гіпертонічною хворобою (ГХ) у поєднанні з облітеруючим атеросклерозом нижніх кінцівок (ОАНК) важливим $€$ питання вегетативної нервової регуляції, адже вона безпосередньо впливає на регулювання діяльності серцево-судинної системи, на формування типу ЦГ, на тонус магістральних і колатеральних судин. При хронічній артеріальній недостатності нижніх кінцівок (ХАНHК) $є$ певні особливості впливу вегетативної нервової системи (ВНС) на ЦГ і ПГ, які необхідно враховувати при виборі медикаментозного лікування $[1,2,6]$.

Мета дослідження - вивчити вплив стану вегетативної нервової системи на центральну і периферійну гемодинаміку пацієнтів з гіпертонічною хворобою, поєднаною з облітеруючим атеросклерозом нижніх кінцівок.

Матеріал і методи дослідження. Обстежено 106 хворих з ГХ+ОАНК із 2-3 ступенями артеріальної гіпертензії (АГ), ІІ стадії ГX і ІІА-ІІІА стадіями ХАННК, яким виконані реваскуляризуючі оперативні втручання для усунення ХАННК. Підтвердження діагнозу АГ проводили на основі критеріїв Європейського товариства кардіологів (ESC) і $\epsilon_{\text {B- }}$ ропейського товариства гіпертензії (ESH) 2018 р., а також настанов Американської колегії кардіологів / Американської асоціації серця (АСС/АНА) 2017 р. Підтвердження діагнозу ОАНК і встановлення стадії ХАННК проводили на основі критеріїв
Рекомендацій Європейського товариства кардіологів з діагностики та лікування захворювань периферійних артерій 2016 р. [7, 9]. Визначення стану ЦГ і ПГ проводили за допомогою програмноапаратного комплексу автоматизованого аналізу реокардіограм УСРГ-01 «CARDIO» (2002). Аналізували ударний об'єм серця (УО), ударний індекс (УІ), хвилинний об'єм кровотоку (ХОК), серцевий індекс $(\mathrm{Cl})$, загальний периферійний судинний опір

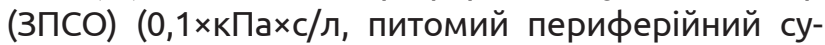
динний опір (ППСО) $\left(0,1 \times \kappa П а \times с /\left(л \times M^{2}\right)\right.$. Визначення стану ВНС проводили шляхом математичного аналізу серцевих скорочень, визначали такі показники: мода $\left(\mathrm{M}_{0}\right)$ - значення тривалості інтервалу, що трапляється найчастіше, с; амплітуда моди $\left(\mathrm{AM}_{0}\right)-$ частота виявлення моди від загального числа розтягнутих інтервалів, \%; $\Delta \mathrm{X}$ - (варіаційний розмах) характеризує ступінь зміни ряду інтервалів; (IH) індекс напруги; ВПР - вегетативний показник ритму [10].

Ультразвукові дослідження судин нижніх кінцівок проводили на апараті LODGIQ (США) датчиком лінійного формату із частотою ультразвукового випромінювання від 5 до 15 МГц. Дуплексне сканування артерій аорто-стегново-підколінногомілкового сегмента і сонних артерій давало інформацію про товщину, форму, структуру та межі артеріальної стінки, діаметр просвіту на рівні стенотичної та післястенотичної ділянок, їх прохідність у В-режимі. Також оцінювали гемодинамічні 
Огляди літератури, оригінальні дослідження, погляд на проблему, випадок з практики, короткі повідомлення феномени з використанням ефекту Доплера [3]. Якісну оцінку кровотоку отримували із кольорового доплерівського режиму, кількісну - із спектрального. Спектральний доплерівський режим давав нам можливість отримувати наступні кількісні дані про кровотік аорто-стегново-підколінно-гомілковим сегментом: пікова систолічна швидкість - $\left(\mathrm{V}_{\mathrm{ps}}\right.$ - peak systolic velocity $)$ - максимальна швидкість кровотоку під час систоли; максимальна кінцева діастолічна швидкість $\left(\mathrm{V}_{\text {ed }}\right.$ - end diastolic velocity) - максимальна швидкість кровотоку в кінці діастоли; систолічно-діастолічне співвідношення (S/D) - співвідношення величини пікової систолічної швидкості до величини максимальної кінцевої діастолічної швидкості кровотоку $-\mathrm{S} / \mathrm{D}=\mathrm{V}_{\mathrm{ps}} / \mathrm{V}_{\mathrm{ed}}$. Характеризує еластичність артеріальної стінки. RI - індекс периферійного опору - відношення різниці пікової систолічної та максимальної діастолічної швидкостей кровотоку до пікової систолічної швидкості; IP (індекс пульсації) - відношення різниці пікової систолічної та максимальної кінцевої діастолічної швидкостей кровотоку до середньої за часом максимальної швидкості кровотоку; $\mathrm{V}_{\text {vol }}$ об'ємна швидкість, що є добутком площі поперечного перерізу судин на середню за часом швидкість кровотоку та індекс пульсації (з використанням останнього величина наближається до реальної) $[4,5]$.

Результати й обговорення. У 56 пацієнтів групи дослідження $(52,8 \%)$ було виявлено симпатотонічний тип ВНС, а у 50 хворих $(47,2 \%)$ - ваготонічний тип ВНС (табл. 1). Було встановлено, що для ваготонічного типу ВНС характерним $\epsilon$ зменшення індексу напруги (IH) до $(49,1 \pm 4,3)$, амплітуди моди $\left(A M_{0}\right)$ до $(39,5 \pm 1,5) \%$ і збільшення варіаційного розмаху низки інтервалів $(\Delta \mathrm{X})$ до $(0,34 \pm 0,06)$ у порівнянні з нормативними показниками за Р. М. Баєвським (2001р.). За результатами вегетативного показника ритму (ВПР) та індексу вегетативної реакції (IBP) можна говорити про переважання одного із типів вегетативної реакції. Так, чим менша величина ВПР, тим більше вегетативний баланс зміщений у бік переважання парасимпатичного типу. При ваготонічному типі ВПР був на рівні $(2,63 \pm$ $0,35)$ с, що $\epsilon$ нижчим за норму. IBP характеризує співвідношення між активністю симпатичного та парасимпатичного відділів ВНС, при ваготонічному типі він становив $(154,90 \pm 8,53)$ ум. од. Так, показник АМ при симпатотонічному типі ВНС збільшився на $15,5 \%(p<0,01)$, показник IH - зріс в 2,2 раза, а показник $\Delta \mathrm{X}$ зменшився у 2,3 раза з одночасним збільшенням величини ІВР та ВПР у 2,3 раза і в 3,7 раза, порівняно з ваготоніками. Чим нижча величина показника $\mathrm{AM}_{0}$ і вищий показник $\Delta \mathrm{X}$, тим більше виражена активність парасимпатичного відділу ВНС (відмічається обернено-пропорційний взаємозв'язок показників).

Таблиця 1. Стан вегетативної нервової системи у хворих на гіпертонічну хворобу в поєднанні з облітеруючим атеросклерозом нижніх кінцівок після оперативних втручань

\begin{tabular}{|c|c|c|c|c|}
\hline \multirow{2}{*}{$\begin{array}{c}\text { Показник } \\
\text { ВНС }\end{array}$} & \multicolumn{3}{|c|}{ Група за типом ВНС } & \multirow[b]{2}{*}{$P_{1-2-3}$} \\
\hline & $\begin{array}{l}\text { група контролю } \\
(\mathrm{n}=20)\end{array}$ & $\begin{array}{l}\text { симпатотонічний тип ВНС } \\
(n=56)\end{array}$ & $\begin{array}{c}\text { ваготонічний тип ВНС } \\
(n=50)\end{array}$ & \\
\hline$M_{0}, C$ & $0,80 \pm 0,04$ & $0,63 \pm 0,06$ & $0,93 \pm 0,02$ & $\begin{array}{l}\mathrm{P}_{1-2}<0,05 \\
\mathrm{P}_{1-3}<0,05 \\
\mathrm{P}_{2-3}<0,05\end{array}$ \\
\hline $\mathrm{AM}_{0}, \%$ & $43,0 \pm 0,9$ & $49,7 \pm 1,8$ & $39,5 \pm 1,5$ & $\begin{array}{l}\mathrm{P}_{1-2}<0,05 \\
\mathrm{P}_{1-3}<0,05 \\
\mathrm{P}_{2-3}<0,05\end{array}$ \\
\hline$\Delta X, c$ & $0,21 \pm 0,01$ & $0,09 \pm 0,04$ & $0,34 \pm 0,06$ & $\begin{array}{l}\mathrm{P}_{1-2}<0,05 \\
\mathrm{P}_{1-3}<0,05 \\
\mathrm{P}_{2-3}<0,05\end{array}$ \\
\hline IH, ум. од. & $110,0 \pm 11,1$ & $238,4 \pm 13,5$ & $49,1 \pm 4,3$ & $\begin{array}{l}\mathrm{P}_{1-2}<0,05 \\
\mathrm{P}_{1-3}<0,05 \\
\mathrm{P}_{2-3}<0,05\end{array}$ \\
\hline IBР, ум. од. & $232,79 \pm 8,53$ & $530,45 \pm 16,98$ & $154,90 \pm 8,53$ & $\begin{array}{l}\mathrm{P}_{1-2}<0,05 \\
\mathrm{P}_{1-3}<0,05 \\
\mathrm{P}_{2-3}<0,05\end{array}$ \\
\hline $\mathrm{B} \Pi \mathrm{P}, \mathrm{C}$ & $4,25 \pm 0,64$ & $15,87 \pm 0,32$ & $2,63 \pm 0,35$ & $\begin{array}{l}\mathrm{P}_{1-2}<0,05 \\
\mathrm{P}_{1-3}<0,05 \\
\mathrm{P}_{2-3}<0,05\end{array}$ \\
\hline
\end{tabular}

Примітка. * - p--2-3 $_{2}$ достовірність різниці показників між групами хворих з різними типами ВНС та групою контролю. 
Огляди літератури, оригінальні дослідження, погляд на проблему, випадок з практики, короткі повідомлення

Як при атеросклеротичній оклюзії аорто-клубово-стегнового сегмента, так і при оклюзії стегново-підколінно-гомілкового сегмента (СПГС) збільшення периферійного судинного опору безпосередньо впливає на функцію серцево-судинної системи. Тому виникає необхідність інтерпретації показників ЦГ із показниками ВНС, а також проведення їх аналізу для прогнозування можливості виникнення ускладнень як з боку ішемізованої кінцівки, таких як прогресування ішемії та тромбозу, так і з боку серцевої-судинної системи у цілому.

При аналізі показників УІ та СІ при різних типах ЦГ у хворих з симпатотонічним і вагото- нічним типами ВНС було встановлено, що різним типам ЦГ відповідає переважання симпатичного або парасимпатичного відділів ВНС (рис. 1). Так, пацієнти з гіперкінетичним типом ЦГ у переважній більшості були симпатотоніками, а пацієнти з гіпокінетичним типом ЦГ - ваготоніками. У групі пацієнтів з еукінетичним типом ЦГ не було суттєвої переваги типів ВНС. Симпатотонічний тип ВНС був у 56 хворих, із них у 35 хворих (61,8 \%) з гіперкінетичним типом ЦГ, у 17 хворих (29,4\%) з еукінетичним типом ЦГ, а в 4 хворих $(8,8 \%)$ - 3 гіпокінетичним типом ЦГ.

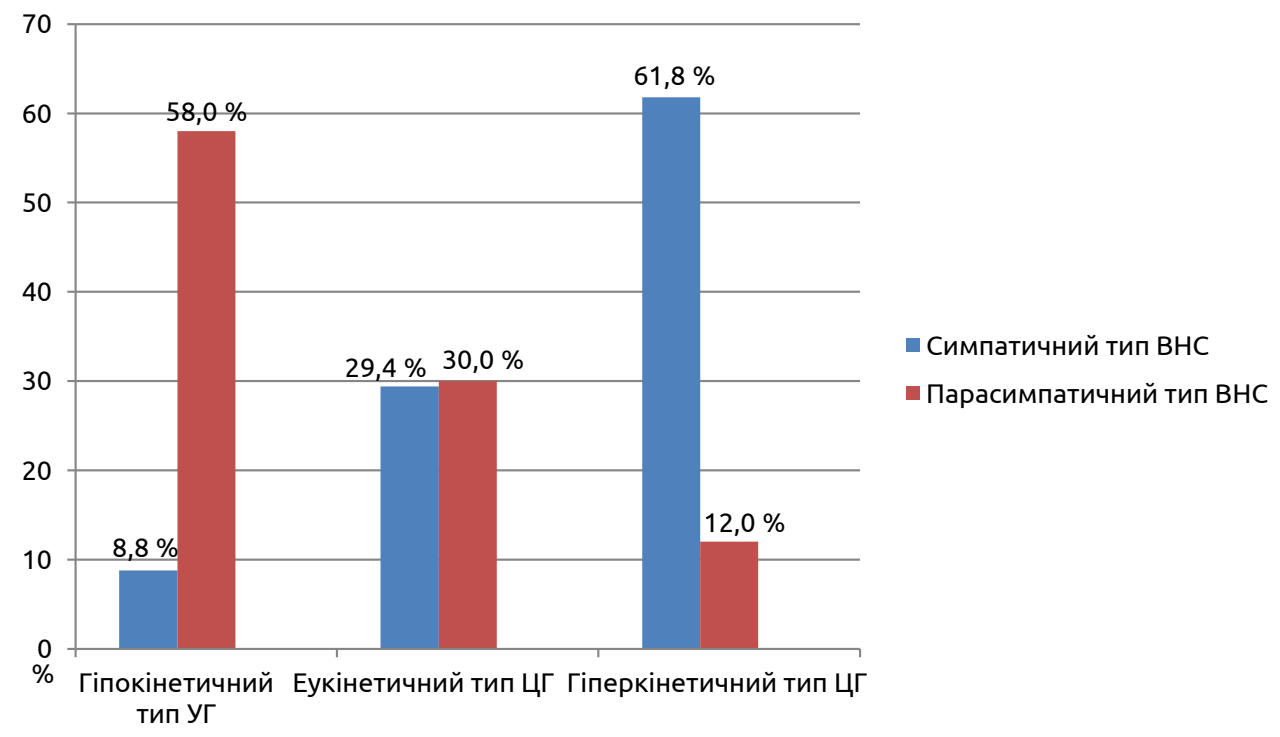

Рис. 1. Розподіл хворих із переважанням симпатичного та парасимпатичного компонентів вегетативної нервової системи залежно від типу центральної гемодинаміки.

У 51 хворого з ваготонічним типом ВНС гіпокінетичний тип ЦГ був у 29 хворих (58,0\%), еукінетичний тип ЦГ був у 15 хворих $(30,0 \%)$, а в 6 хворих (12,0\%) - гіперкінетичний тип ЦГ. Таким чином, було встановлено, що в групи хворих на ГХ у поєднанні з ХАННК відповідає певний тип BHC, гіперкінетичному типу ЦГ відповідає переважання симпатичних відділу ВНС над парасимпатичним (61,8 \%), а при гіпокінетичному типі - переважання парасимпатичного відділу ВНС над симпатичним $(58,0 \%)$ та відповідні зміни в колатеральному кровообігу нижніх кінцівок. При аналізі даних ПГ за показниками сонографії в проекційних точках на низхідній артерії коліна (НАК), задній великогомілковій артерії (ЗВГА) та на передній великогомілковій артерії (ПВГА) отримано результати, які представлені у таблицях 2 і 3.

Таблиця 2. Показники ПГ на НАК, ЗВГА, ПВГА у хворих із переважанням симпатичного компонента ВНС

\begin{tabular}{|c|c|c|c|c|}
\hline \multirow{2}{*}{$\begin{array}{c}\text { Локалізація визначення } \\
\text { показників УзД/ } \\
\text { Показник периферійної } \\
\text { гемодинаміки }\end{array}$} & \multicolumn{3}{|c|}{ Тип центральної гемодинаміки у хворих основної групи } & \multirow[b]{2}{*}{$P_{1-2-3}$} \\
\hline & $\begin{array}{c}\text { гіперкінетичний тип, } \\
1 \text { підгрупа } \\
(n=35)\end{array}$ & $\begin{array}{c}\text { еукінетичний тип, } \\
2 \text { підгрупа } \\
(n=17)\end{array}$ & $\begin{array}{c}\text { гіпокінетичний тип, } \\
3 \text { підгрупа } \\
(n=4)\end{array}$ & \\
\hline 1 & 2 & 3 & 4 & 5 \\
\hline$\underline{H A K}: \mathrm{V}_{\mathrm{ps}, \mathrm{cm} / \mathrm{c}}$ & $59,7 \pm 2,9$ & $47,3 \pm 1,4$ & $38,7 \pm 2,6$ & $\begin{array}{l}\mathrm{P}_{1-2}<0,05 \\
\mathrm{P}_{1-3}<0,01 \\
\mathrm{P}_{2-3}<0,05\end{array}$ \\
\hline
\end{tabular}


Огляди літератури, оригінальні дослідження, погляд на проблему, випадок з практики, короткі повідомлення

Продовження табл. 2

\begin{tabular}{|c|c|c|c|c|}
\hline 1 & 2 & 3 & 4 & 5 \\
\hline $\mathrm{V}_{\mathrm{ed}, \mathrm{cm} / \mathrm{c}}$ & $11,8 \pm 1,1$ & $8,3 \pm 0,9$ & $5,5 \pm 1,1$ & $\begin{array}{l}\mathrm{P}_{1-2}<0,05 \\
\mathrm{P}_{1-3}<0,01 \\
\mathrm{P}_{2-3}<0,05\end{array}$ \\
\hline $\mathrm{V}_{\mathrm{vol}, \mathrm{M} / \mathrm{xB}}$ & $52,1 \pm 5,7$ & $36,1 \pm 5,7$ & $20,0 \pm 4,0$ & $\begin{array}{l}\mathrm{P}_{1-2}<0,05 \\
\mathrm{P}_{1-3}<0,01 \\
\mathrm{P}_{2-3}<0,05\end{array}$ \\
\hline ЗВГГА: $V_{p s, c m / c}$ & $58,8 \pm 3,5$ & $45,2 \pm 2,4$ & $36,7 \pm 2,7$ & $\begin{array}{l}\mathrm{P}_{1-2}<0,01 \\
\mathrm{P}_{1-3}<0,01 \\
\mathrm{P}_{2-3}<0,05\end{array}$ \\
\hline $\mathrm{V}_{\mathrm{ed}, \mathrm{cm} / \mathrm{c}}$ & $11,9 \pm 1,1$ & $8,3 \pm 1,1$ & $5,1 \pm 1,1$ & $\begin{array}{l}\mathrm{P}_{1-2}<0,05 \\
\mathrm{P}_{1-3}<0,01 \\
\mathrm{P}_{2-3}>0,05\end{array}$ \\
\hline $\mathrm{V}_{\mathrm{vol}, \mathrm{M} / \mathrm{xB}}$ & $11,2 \pm 1,5$ & $7,4 \pm 1,0$ & $4,4 \pm 1,1$ & $\begin{array}{l}\mathrm{P}_{1-2}<0,05 \\
\mathrm{P}_{1-3}<0,01 \\
\mathrm{P}_{2-3}<0,05\end{array}$ \\
\hline$\underline{\text { ПВГА: }} \mathrm{V}_{\mathrm{ps}, \mathrm{cm} / \mathrm{c}}$ & $61,1 \pm 1,4$ & $51,7 \pm 1,6$ & $46,9 \pm 3,7$ & $\begin{array}{l}\mathrm{P}_{1-2}<0,01 \\
\mathrm{P}_{1-3}<0,01 \\
\mathrm{P}_{2-3}<0,05\end{array}$ \\
\hline $\mathrm{V}_{\mathrm{ed}, \mathrm{cm} / \mathrm{c}}$ & $11,9 \pm 0,9$ & $8,8 \pm 1,1$ & $5,5 \pm 1,2$ & $\begin{array}{l}\mathrm{P}_{1-2}<0,05 \\
\mathrm{P}_{1-3}<0,01 \\
\mathrm{P}_{2-3}<0,05\end{array}$ \\
\hline $\mathrm{V}_{\mathrm{vol}, \mathrm{M} / \mathrm{xB}}$ & $5,9 \pm 0,5$ & $3,9 \pm 0,8$ & $2,0 \pm 0,5$ & $\begin{array}{l}\mathrm{P}_{1-2}<0,05 \\
\mathrm{P}_{1-3}<0,01 \\
\mathrm{P}_{2-3}<0,05\end{array}$ \\
\hline
\end{tabular}

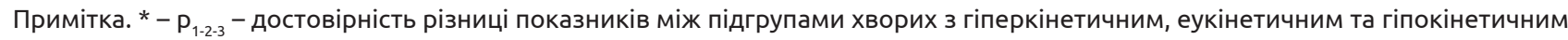
типами гемодинаміки.

Таблиця 3. Показники ПГ на НАК, ЗВГА, ПВГА у хворих із переважанням парасимпатичного компонента ВНС

\begin{tabular}{|c|c|c|c|c|}
\hline \multirow{2}{*}{$\begin{array}{c}\text { Локалізація } \\
\text { визначення } \\
\text { показників УЗД/ } \\
\text { Показник ПГ }\end{array}$} & \multicolumn{3}{|c|}{ Тип ЦГ у хворих основної групи } & \multirow[b]{2}{*}{$P_{1-2-3}$} \\
\hline & $\begin{array}{c}\text { гіперкінетичний тип, } \\
1 \text { підгрупа } \\
(n=6)\end{array}$ & $\begin{array}{c}\text { еукінетичний тип, } \\
2 \text { підгрупа } \\
\text { (n=15) }\end{array}$ & $\begin{array}{c}\text { гіпокінетичний тип, } \\
3 \text { підгрупа } \\
\text { (n=29) }\end{array}$ & \\
\hline 1 & 2 & 3 & 4 & 5 \\
\hline$\underline{\mathrm{HAK}}: \mathrm{V}_{\mathrm{ps}, \mathrm{cm} / \mathrm{c}}$ & $52,1 \pm 1,2$ & $46,1 \pm 1,1$ & $34,4 \pm 1,0$ & $\begin{array}{l}\mathrm{P}_{1-2}<0,01 \\
\mathrm{P}_{1-3}<0,01 \\
\mathrm{P}_{2-3}<0,01\end{array}$ \\
\hline$V_{\text {ed, } c m / c}$ & $9,8 \pm 0,8$ & $7,4 \pm 0,9$ & $5,1 \pm 0,7$ & $\begin{array}{l}\mathrm{P}_{1-2}<0,05 \\
\mathrm{P}_{1-3}<0,01 \\
\mathrm{P}_{2-3}<0,05\end{array}$ \\
\hline $\mathrm{V}_{\mathrm{vol}, \mathrm{M} \pi / \times \mathrm{B}}$ & $47,9 \pm 6,5$ & $30,4 \pm 5,1$ & $17,7 \pm 3,1$ & $\begin{array}{l}\mathrm{P}_{1-2}<0,05 \\
\mathrm{P}_{1-3}<0,01 \\
\mathrm{P}_{2-3}<0,05\end{array}$ \\
\hline$\underline{3 B Г A:} V_{p s, c m / c}$ & $50,7 \pm 1,6$ & $41,9 \pm 2,1$ & $30,4 \pm 2,4$ & $\begin{array}{l}P_{1-2}<0,01 \\
P_{1-3}<0,01 \\
P_{2-3}<0,01\end{array}$ \\
\hline
\end{tabular}


Огляди літератури, оригінальні дослідження, погляд на проблему, випадок з практики, короткі повідомлення

Продовження табл. 3

\begin{tabular}{|c|c|c|c|c|}
\hline 1 & 2 & 3 & 4 & 5 \\
\hline$V_{e d, c m / c}$ & $10,2 \pm 0,9$ & $7,6 \pm 0,8$ & $4,5 \pm 1,0$ & $\begin{array}{l}\mathrm{P}_{1-2}<0,05 \\
\mathrm{P}_{1-3}<0,01 \\
\mathrm{P}_{2-3}<0,05\end{array}$ \\
\hline $\mathrm{V}_{\mathrm{vol}, \mathrm{M} \Omega / \mathrm{xB}}$ & $10,1 \pm 1,0$ & $6,3 \pm 1,1$ & $3,6 \pm 0,8$ & $\begin{array}{l}\mathrm{P}_{1-2}<0,05 \\
\mathrm{P}_{1-3}<0,01 \\
\mathrm{P}_{2-3}<0,05\end{array}$ \\
\hline$\underline{\Pi B \Gamma A:} \vee_{\mathrm{ps}, \mathrm{cm} / \mathrm{c}}$ & $51,8 \pm 1,4$ & $47,5 \pm 1,0$ & $35,1 \pm 1,3$ & $\begin{array}{l}\mathrm{P}_{1-2}<0,05 \\
\mathrm{P}_{1-3}<0,01 \\
\mathrm{P}_{2-3}<0,01\end{array}$ \\
\hline$V_{e d, c m / c}$ & $9,7 \pm 0,8$ & $7,6 \pm 0,7$ & $4,3 \pm 1,1$ & $\begin{array}{l}\mathrm{P}_{1-2}<0,05 \\
\mathrm{P}_{1-3}<0,01 \\
\mathrm{P}_{2-3}<0,05\end{array}$ \\
\hline$V_{\text {vol, Mn } / \times B}$ & $4,3 \pm 0,5$ & $2,9 \pm 0,5$ & $1,5 \pm 0,5$ & $\begin{array}{l}\mathrm{P}_{1-2}<0,05 \\
\mathrm{P}_{1-3-3}<0,01 \\
\mathrm{P}_{2-3}<0,05\end{array}$ \\
\hline
\end{tabular}

Примітка. * - p $1-2-3_{-3}$ достовірність різниці показників між підгрупами хворих з гіперкінетичним, еукінетичним та гіпокінетичним типами гемодинаміки.

Привертає увагу те, що у хворих із переважанням симпатотонічного компонента на НAK при гіперкінетичному типі ЦГ показник $\mathrm{V}_{\mathrm{ps}}$ був вищим на $26,2 \%(p<0,05)$, а при гіпокінетичному типі ЦГ - показник $\mathrm{V}_{\mathrm{ps}}$ був нижчим на $18,2 \%(p<0,05)$, порівняно з аналогічним показником у хворих 3 еукінетичним типом ЦГ. Також зафіксовано збільшення показника $\mathrm{V}_{\text {ed }}$ при гіперкінетичному та еукінетичному типах ЦГ відповідно на $42,1 \%(p<0,01)$ та на $53,4 \%(p<0,01)$, порівняно з гіпокінетичним типом ЦГ. Така різниця показника $\mathrm{V}_{\text {ed }}$ впливає на показник $\mathrm{V}_{\text {vol }}$ при різному тонусі ВНС. Так, показник $\mathrm{V}_{\text {vol }}$ при гіперкінетичному типі ЦГ був вищим на $44,3 \%(p<0,01)$, а при гіпокінетичному - на $44,6 \%$ $(p<0,01)$, порівняно із групою пацієнтів, у яких переважав парасимпатичний компонент ВНС.

У хворих із переважанням симпатичного відділу ВНС на ЗВГА при гіперкінетичному типі ЦГ показник $\mathrm{V}_{\mathrm{ps}}$ був вищим на $30,0 \%(p<0,01)$, а при гіпокінетичному типі ЦГ показник $\mathrm{V}_{\mathrm{ps}}$ був нижчим на $18,9 \%(p<0,05)$, порівняно з аналогічним показником у хворих з еукінетичним типом ЦГ. Показник $\mathrm{V}_{\text {еd }}$ був вищим у хворих з гіперкінетичним типом ЦГ на 43,3\% ( $<<0,01)$, а у хворих з гіпокінетичним типом ЦГ цей показник був нижчим на $39,6 \%$ $(p<0,01)$, порівняно з аналогічним показником у хворих з еукінетичним типом ЦГ. Значно вища $\mathrm{V}_{\mathrm{ps}}$ створює високий градієнт тисків між рівнями оклюзійного процесу в СПГС. Це створює у хворихсимпатотоніків додаткові можливості для перерозподілу кровотоку резервними колатеральними шляхами, і таким чином збільшуються функціональні параметри кровотоку в магістральних артеріях у дистальних відділах кінцівок. Ці позитивні явища в гемодинаміці найбільше притаманні хворим із гіперкінетичним типом ЦГ. Також помічено, що у хворих-симпатотоніків показник $\mathrm{V}_{\mathrm{ps}}$ на ПВГА переважав показник $\mathrm{V}_{\text {ps }}$ на ЗВГА при гіпокінетичному типі ЦГ на $21,8 \%(p<0,01)$, а у хворих з гіперкінетичним та еукінетичним типами перевага становила $3,8 \%(p>0,05)$ та $12,6 \%(p<0,05)$ відповідно.

При переважанні парасимпатичного компонента ВНС різниця між показниками $\mathrm{V}_{\mathrm{ps}}$ на ПВГА та ЗВГА не була значною. Так, збільшення $\mathrm{V}_{\text {ps }}$ на ПВГА при гіперкінетичному типі ЦГ було на 2,2 \% ( $>>0,05)$, при еукінетичному типі Цг - на $11,8 \%$ $(p<0,05)$ та при гіпокінетичному - на $13,4 \%$ $(p<0,05)$, що вказувало на меншу компенсаторну можливість судин.

Якщо порівняти показник $V_{\text {vol }}$ у хворих симпатотоніків і парасимпатотоніків, то останній був вищим у першої групи хворих, особливо при еу- та гіпокінетичному типі ЦГ. Зокрема, показник $\mathrm{V}_{\text {vol }}$ на ЗВГА при гіперкінетичному типі ЦГ був вищим на $10,8 \%(p<0,05)$ у симпатотоніків, при еукінетичному типі ЦГ показник $\mathrm{V}_{\text {vol }}$ був вищим на $17,4 \%$ $(p<0,05)$, а при гіпокінетичному типі ЦГ - на $22,2 \%$ $(p<0,01)$, порівняно з аналогічними показниками у парасимпатотоніків. На ПВГА показник $\mathrm{V}_{\text {vol }}$ У двох групах хворих при порівнянні симпатотоніків і ваготоніків був таким: при гіперкінетичному типі показник $V_{\text {vol }}$ був вищим на $37,2 \%(p<0,01)$, при еукінетичному типі показник був вищим на $13,1 \%$ $(p<0,05)$, а при гіпокінетичному типі - на $33,3 \%$ $(p<0,05)$ вищим у групі хворих з переважанням 
Огляди літератури, оригінальні дослідження, погляд на проблему, випадок з практики, короткі повідомлення симпатикотонії. Подібна різниця показника $\mathrm{V}_{\text {vol }}$ може свідчити про кращий компенсаторний стан колатерального русла у хворих симпатотоніків, особливо при гіперкінетичному типі Цг. Наведені вище дані дозволяють стверджувати, що у хворих на ГХ, поєднану із оклюзією магістральних артерій нижніх кінцівок, для гіпокінетичного типу ЦГ властивим є підвищений тонус парасимпатичного компонента, а для гіперкінетичного, навпаки, - симпатичного компонента ВНС. При цьому, у хворих з переважанням парасимпатичної нервової системи колатеральна система не має компенсаторного значення і за короткий термін у хворих з еу- та гіперкінетичним типом ЦГ втрачає свою компенсаторну функцію. Водночас у хворих з переважанням симпатичної нервової системи колатеральне русло $\epsilon$ достатньо розвинутим, з максимальною кількістю функціонуючих колатеральних гілок, особливо при гіпер- та еукінетичному типах ЦГ, а в умовах гіпокінетичного типу ЦГ на тлі переважання парасимпатичного компонента ВНС відмічено краще кровопостачання дистального сегмента кінцівки.

Висновки. У пацієнтів з гіпертонічною хворобою у поєднанні з ОАНК після проведених реконструктивних оперативних втручань встановили три типи гемодинаміки: гіперкінетичний тип - у 32,1 \% пацієнтів (підвищення $\mathrm{Cl}$ понад 3,7 л/(хвхм²) при зниженні ППСО менше 110,0 0,1×кПахс/(л×м²)), гіпокінетичний тип - у 38,7 \% (зниження СІ менше 2,2 л/(хв×м²) при одночасному підвищенні ППСО понад 190,0 0,1×кПахс/(л×м²)); еукінетичний тип у 29,2 \% (значення Сl і ППСО були у межах вищеназваних типів гемодинаміки).

При гіпертонічній хворобі у поєднанні із ОАНК з гіпокінетичним типом гемодинаміки у 59,1% пацієнтів було констатовано підвищення тонусу парасимпатичного компонента ВНС і наявність недостатньо розвинутого колатерального русла нижніх кінцівок, а в 89,3 \% з еу- та гіперкінетичним типами гемодинаміки - переважання симпатичного компонента ВНС із достатньо розвинутим колатеральним руслом, що здатне до посилення функціонального навантаження.

Перспективи подальших досліджень. Вважаємо актуальним проведення дослідження ефективності лікування хворих на гіпертонічну хворобу у поєднанні з облітеруючим атеросклерозом нижніх кінцівок із застосуванням різних комбінацій базисних антигіпертензивних препаратів у практиці сімейного лікаря.

\section{ЛІТЕРАТУРА}

1. Артеріальна гіпертензія. Стандарти надання медичної допомоги лікарями первинної ланки //Укр. мед. часопис. - 2018. - № 5 (127), T.1, IX/X. - С. 2-10.

2. Долженко М. М. Європейські рекомендації з ведення хворих на артеріальну гіпертензію 2018: фокус на ішемічну хворобу серця / М. М. Долженко, І. В. Давидова, О. В. Шершнева // Здоров'я України. - 2018. № 15, Т. 16 (436-437).- С. 35-37.

3. Уніфікований клінічний протокол первинної, вторинної (спеціалізованої) та третинної (високоспеціалізованої) медичної допомоги. Профілактика серцево-судинних захворювань: Наказ МОЗ України від 13.06.2016 p. № 564 [Електронний ресурс]. - Режим доступу: http:// moz.gov.ua/ua/portal/dn_20060703_436.html.

4. Волошина О. Б. Сучасні рекомендації щодо діагностики та лікування захворювань артерій нижніх кінцівок у практиці сімейного лікаря (огляд літератури) / О. Б. Волошина // Сімейна медицина. - 2017. - № 4 (72). С. 48-54.

5. Шлант Р. К. Клиническая кардиология / Р. К. Шлант, Р. В. Александер. - М. - СПб. : Издательство БИНОМ Невский проспект, 2017. - 576 с.

6. $2018 \mathrm{ESC} / \mathrm{ESH}$ Guidelines for themanagement of arterial hypertension // European Heart Journal. - 2018. Vol. 39, Issue 33. - P. 3021-3104.

7. 2016 ESC/EAS Guidelines for the Management of Dyslipidaemias: The Task Force for the Management of Dyslipidaemias of the European Society of Cardiology (ESC) and European Atherosclerosis Society (EAS) Developed with the special contribution of the European Assocciation for Cardiovascular Prevention \& Rehabilitation (EACPR) / A. L. Catapano, I. Graham, G. De Backer [et al.] // Eur. Heart J. - 2016. - Vol. 37 (38). - P. 2999-3058.

8. Peripheral arterial disease and critical limb ischaemia: still poor outcomes and lack of guideline adherence / H. Reinecke, M. Unrath, E. Freisinger [et al.] // Eur. Heart. J. 2015. - Vol. 36. - P. 932-938.

9. ESC Committee for Practice Guidelines. ESC Guidelines on the diagnosis and treatment of peripheral artery diseases: document covering atherosclerotic disease of extracranial carotid and vertebral, mesenteric, renal, upper and lower extremity arteries. The Task Force on the Diagnosis and Treatment of Peripheral Artery Diseases of the European Society of Cardiology (ESC) / M. Tendera, V. Aboyans, M. L. Bartelink [et al.] // Eur. Heart. J. - 2011. Vol. 32. - P. 2851-2906.

10. World Health Organization. Global Health Observatory: raised blood pressure. Access mode : http://www. who.int/gho/ncd/risk_factors/blood_pressure_prevalence_text/en/. Accessēd August 12, 2014. 
Огляди літератури, оригінальні дослідження, погляд на проблему, випадок з практики, короткі повідомлення REFERENCES

1. (2018). Arterialna hipertenziia. Standarty nadannia medychnoi dopomohy likariamy pervynnoi lanky [Arterial hypertension. Standards for the provision of medical care by primary care physicians]. Ukrainskyi medychnyi chasopys Ukrainian Medical Journal, 5(127), 1, IX/X, 2-10 [in Ukrainian].

2. Dolzhenko, M.M., Davydova, I.V., \& Shershneva, O.V. (2018). Yevropeiski rekomendatsii z vedennia khvorykh na arterialnu hipertenziiu 2018: fokus na ishemichnu khvorobu sertsia [European guidelines for the management of patients with hypertension in 2018: focus on coronary heart disease]. Zdorovia Ukrainy - Health of Ukraine, 15-16 (436437), 35-37 [in Ukrainian].

3. Nakaz MOZ Ukrainy vid 13.06.2016 r. №564 "Unifikovanyi klinichnyi protokol pervynnoi, vtorynnoi (spetsializovanoi) ta tretynnoi (vysokospetsializovanoi) medychnoi dopomohy. Profilaktyka sertsevo-sudynnykh zakhvoriuvan" [Order of the Ministry of Health of Ukraine dated June 13, 2016, No. 564 "Unified clinical protocol of primary, secondary (specialized) and tertiary (highly specialized) medical care. Prevention of Cardiovascular Diseases"]. Retrieved from: http:// moz.gov.ua/ua/portal/dn_20060703_436.html [in Ukrainian].

4. Voloshyna, O.B. (2017). Suchasni rekomendatsii shchodo diahnostyky ta likuvannia zakhvoriuvan arterii nyzhnikh kintsivok u praktytsi simeinoho likaria (ohliad literatury) [Modern recommendations on the diagnosis and treatment of lower limb arteries in the practice of a family doctor (review of literature)]. Simeina medytsyna - Family Medicine, 4 (72), 48-54 [in Ukrainian].

5. Shlant, R.K., \& Aleksander, R.V. (2017). Klinicheskaya kardiologiya [Clinical cardiology]. Izdatelstvo BYNOM, Nevskyy prospekt [in Russian].

6. (2018). ESC/ESH Guidelines for the management of arterial hypertension. European Heart Journal, 39 (33), 3021-3104.

7. Catapano, A.L., Graham, I., \& De Backer, G. (2016). 2016 ESC/EAS Guidelines for the Management of Dyslipidaemias: The Task Force for the Management of Dyslipidaemias of the European Society of Cardiology (ESC) and European Atherosclerosis Society (EAS) Developed with the special contribution of the European Assocciation for Cardiovascular Prevention \& Rehabilitation (EACPR). European Heart Journal, 37 (38), 2999-3058.

8. Reinecke, H., Unrath, M., \& Freisinger, E. (2015). Peripheral arterial disease and critical limb ischaemia: still poor outcomes and lack of guideline adherence. European Heart Journal, 36, 932-938.

9. Tendera, M., Aboyans, V., \& Bartelink, M.L. (2011). ESC Committee for Practice Guidelines. ESC Guidelines on the diagnosis and treatment of peripheral artery diseases: document covering atherosclerotic disease of extracranial carotid and vertebral, mesenteric, renal, upper and lower extremity arteries. The Task Force on the Diagnosis and Treatment of Peripheral Artery Diseases of the European Society of Cardiology (ESC). European Heart Journal, 32, 2851-2906.

10. World Health Organization. Global Health Observatory: raised blood pressure. Retrieved from: http://www.who.int/gho/ncd/risk_factors/blood_ pressure_prevalence_text/en/.

\title{
ВЛИЯНИЕ СОСТОЯНИЯ ВЕГЕТАТИВНОЙ НЕРВНОЙ СИСТЕМЫ НА ГЕМОДИНАМИКУ ПАЦИЕНТОВ С ГИПЕРТОНИЧЕСКОЙ БОЛЕЗНЬЮ В СОЧЕТАНИИ С ОБЛИТЕРИРУЮЩИМ АТЕРОСКЛЕРОЗОМ НИЖНИХ КОНЕЧНОСТЕЙ
}

\author{
๑Л. С. Бабинец, Л. Я. Федонюк, В. В. Билочицкая, Ю. Я. Коцаба \\ Тернопольский национальный медицинский университет имени И. Я. Горбачевского МОз Украины
}

РЕЗЮМЕ. При изучении состояния центральной и периферической гемодинамики у пациентов с гипертонической болезнью в сочетании с облитерирующим атеросклерозом нижних конечностей важным является вопрос вегетативной нервной регуляции.

Цель исследования - изучить влияние состояния вегетативной нервной системы на центральную и периферическую гемодинамику пациентов с гипертонической болезнью в сочетании с облитерирующим атеросклерозом нижних конечностей.

Результаты. У пациентов с гипертонической болезнью в сочетании с облитерирующим атеросклерозом нижних конечностей после проведенных реконструктивных оперативных вмешательств установили три типа гемодинамики: гиперкинетический тип - у 32,1 \% пациентов (повышение СИ более 3,7 л/(мин×м²) при снижении удельного периферического сосудистого сопротивления (УПСС) меньше 110,0 (0,1×кПахс/(лхм²)), гипокинетический тип - у 38,7 \% (снижение СИ менее 2,2 л/(мин×м²) при одновременном повышении УПСС более 190,0 $\left(0,1 \times к П а \times с /\left(л \times м^{2}\right)\right)$ эукинетическим типом - в 29,2 \% (значение СИ и УПСС были в пределах вышеназванных типов гемодинамики).

Вывод. При гипертонической болезни в сочетании с ОАНК с гипокинетическим типом гемодинамики у 59,1\% пациентов было констатировано повышение тонуса парасимпатического компонента ВНС и наличие недостаточно развитого коллатерального русла нижних конечностей, а в 89,3\% с еу- и гиперкинетическим типами гемодинамики - преобладание симпатичного компонента ВНС с достаточно развитым коллатеральным руслом, способным к усилению функциональной нагрузки.

КЛЮчЕВЫЕ СЛОВА: гипертоническая болезнь; облитерирующий атеросклероз нижних конечностей; вегетативная нервная система; периферическая и центральная гемодинамика. 


\section{@L. S. Babinets, L. Ya. Fedoniuk, V. V. Bilochytska, Yu. Ya. Kotsaba I. Horbachevsky Ternopil National Medical University}

SUMMARY. In the study of the state of central hemodynamics $(\mathrm{CH})$ and peripheral hemodynamics (PH) in patients with hypertension in combination with obliterative atherosclerosis of the lower extremities (OALE), the importance of autonomic nervous regulation is important.

The aim of the study - to investigate the effect of the state of the autonomic nervous system on the central and peripheral hemodynamics of patients with hypertension in combination with the obliterative atherosclerosis of the lower extremities.

Results. Three types of hemodynamics were established in hypertensive patients in combination with OALE after the reconstructive surgical interventions: the hyperkinetic type was observed in $32.1 \%$ of patients (elevation of heart index $(\mathrm{HI})$ above $3.7 \mathrm{l} /\left(\mathrm{min} \times \mathrm{m}^{2}\right)$ with a decrease in specific peripheral vascular resistance (SPVR) (less than 110.0 $\left(0.1 \times \mathrm{kPa} \times \mathrm{s} /\left(\left(\times \mathrm{m}^{2}\right)\right)\right.$, the hypokinetic type is $38.7 \%$ (decrease in $\mathrm{HI}$ is less than $2.2 \mathrm{l} /\left(\mathrm{min} \times \mathrm{m}^{2}\right)$ while increasing SPVR over $190.0\left(0.1 \times \mathrm{kPa} \times \mathrm{s} /\left(\left(\mathrm{xm}^{2}\right)\right)\right.$; eukinetic type - in $29.2 \%$ (values of SI and SPVR were within the aforementioned types of hemodynamics).

Conclusion. In hypertonic disease in combination with obliterative atherosclerosis of the lower extremities with a hypokinetic type of hemodynamics, $59.1 \%$ of patients noted an increase in the tonus of the parasympathetic component of the VNS and the presence of an underdeveloped collateral channel of the lower extremities, and $89.3 \%$ of the eu- and hyperkinetic hemodynamic types were prevalence sympathetic component of the VNS with a sufficiently developed collateral channel that is capable of increasing the functional load.

KEY WORDS: hypertonic disease; obliterating lower limb atherosclerosis; autonomic nervous system; peripheral and central hemodynamics. 